RESEARCH ARTICLE

\title{
Role of Cycle Threshold of RT-PCR in the Prediction of COVID-19 Cases
}

Vikramjeet Singh, Jyotsna Agarwal, Jaya Garg, Mohammad Saquib, Anupam Das, Manodeep Sen

${ }^{1}$ Department of Microbiology, Dr. Ram Manohar Lohia Institute of Medical Sciences, Lucknow, Uttar Pradesh, India

\begin{abstract}
Objectives: It is currently unclear whether SARS-CoV-2 Cycle threshold $(\mathrm{Ct})$ values could be leveraged to guide patients' clinical manifestations and management decisions. The present study was undertaken to observe whether RT-PCR Ct values differ in COVID-19 symptomatic and asymptomatic individuals. This study also describes the clinical manifestations and epidemiological characteristics of both groups of patients.
\end{abstract}

Methods: Nasopharyngeal or oropharyngeal swabs of 35,391 clinically suspected COVID-19 patients were collected in VTM and tested in our dedicated COVID-19 diagnostic laboratory for SARS-CoV-2 RT-PCR test. Cycle threshold at day 1 of positive detection was correlated with the presence or absence of the patient's symptoms. The Ct values were studied sequentially in the collected samples to understand the variation of $\mathrm{Ct}$ values with the patient's first day of diagnosis up to the recovery day.

Results: Of 35,391 samples received for RT-PCR, data from 589 COVID-19 diagnosed patients (positivity 1.66\%) was analyzed further. Among 589 patients, a total of 178 patients were symptomatic, while 411 were asymptomatic. Ct values obtained in symptomatic individuals (19.26 \pm 4.34$)$ were significantly lower than in the asymptomatic $(25.96 \pm 4.64)$ individuals $(p<0.01)$. For 38 SARS-CoV-2 positive patients, data from sequential samples submitted to the laboratory was also analyzed. After adjusting for age, gender, co-morbidities, increased cycle threshold was associated with decreased odds of symptoms and in-hospital admission $(0.91, \mathrm{Cl} 0.89-0.94, \mathrm{p}<0.001)$.

Conclusion: Clinical symptoms and laboratory results of RT-PCR (Ct Value) of symptomatic patients with COVID-19 are significantly lower than those without symptoms. Analyzing data from 38 SARSCoV-2 positive patients' sequential samples again demonstrated that symptoms correlate with lower Ct values; however, virus clearance took almost the same time in the two groups of individuals. I Microbiol Infect Dis 2021; 11(3):132-139.

Keywords: SARS-CoV2 RT-PCR, COVID-19 Symptoms, COVID-19 molecular testing, Cycle threshold

\section{INTRODUCTION}

The global outbreak of coronavirus disease 2019 (COVID-19) was officially declared as a pandemic by World Health Organization (WHO) on March 11, 2020, and it has imposed unprecedented, far-reaching impacts upon public health and the global economy [1]. Meanwhile, many studies and international bodies like the CDC and the World Health Organization reporting that many COVID-19 infections might present no or only mild symptoms, with a much higher proportion of asymptomatic infections than previously expected. Therefore, persons with positive reverse transcription-polymerase chain reaction (RT-PCR) results who never develop any signs or clinical symptoms of COVID-19 are considered asymptomatic infected persons. On the other hand, those with positive RT-PCR results who fail to show any signs or symptoms of COVID-19 at testing but later on develop symptoms are considered pre-symptomatic [2]. However, to date, the

Correspondence: Prof. Jyotsna Agarwal, Department of Microbiology, Dr Ram Manohar Lohia Institute of Medical Sciences, Vibhuti Khand, Gomti Nagar, Lucknow, India

E-mail: jyotsnaagarwal.micro@gmail.com

Received: 03 March 2021 Accepted: 05 August 2021

Copyright (C) JMID / Journal of Microbiology and Infectious Diseases 2021, All rights reserved 
exact reasons for being asymptomatic / only mild symptoms in many COVID- 19 patients remain unclear. Still, the role played by these asymptomatic shedders in the transmission of infection is vital.

Symptomatic patients are detected because they seek medical attention. Asymptomatic individuals with SARS-CoV-2 infection could be identified during screening tests or contact tracing via the RT-PCR test for severe acute respiratory syndrome corona virus-2 (SARSCoV-2) [3]. The absolute sensitivity of RT-PCR tests is difficult to ascertain due to the lack of a proper "gold standard." It is dependent on several factors, including specimen type, collection method, and specific test or kit used. Viral loads are inversely related to Cycle threshold $(\mathrm{Ct})$ values and can prove to be an indirect method for quantifying viral RNA in samples. The viral load of SARS-CoV-2 may be an essential factor in determining both disease severity and the likelihood of transmission [4]. SARS-CoV-2 RT-PCR diagnostic results in a clinical setting are usually qualitative, like a binary positive or negative result using a specified threshold based on $\mathrm{Ct}$ value. It is currently unclear whether SARS-CoV-2 Ct values can guide patients' clinical manifestations and management decisions [5].

The present study was undertaken considering the lack of data on the correlation between RTPCR Ct value and the clinical status of patients. Results will shed light on the relationship, if any, between virus load in the nasopharynx and clinical manifestation of COVID-19 disease. It will also help to explore the transmission dynamics of asymptomatic infections and early detection of asymptomatic virus shedders. The epidemiological and clinical features of symptomatic COVID-19 patients are increasingly being reported. This study aims to investigate the course of asymptomatic individuals infected with SARSCoV-2, which is not known enough.

\section{METHODS}

A prospective observational laboratory-based study was conducted in the Department of Microbiology in a tertiary care hospital in North India with a dedicated COVID-19 diagnostic laboratory an Indian Council of Medical Research (ICMR) approved BSL-II lab. Samples in our COVID-19 laboratory are received from 5-7 neighboring districts as per the State administrative policies. The sampling population included symptomatic individuals, contact tracing samples, migrants, and random sampling from asymptomatic individuals. In addition, the following information was extracted from the ICMR case sheets for analysis: 1. Demographic parameters like age and gender; 2. Clinical characteristics such as date of onset.

Throat and/or nasal swabs were submitted to our laboratory in virus transport media (VTM), maintaining the cold chain for the SARS-CoV2 viral nucleic acid detection. For a limited number of patients $(n=38)$, four samples from each (at an interval of 6-7days) were received. In brief, about $140 \mu$ l sample from VTM was pipetted out and transferred to a tube. $560 \mu$ l of lysis buffer was then added to the sample to achieve virus inactivation. RNA extraction was carried out using QIAmp RNA Mini Kit (QIAGEN, Sample and Assay Technology, Hilden, Germany) for all samples. Briefly, $20 \mu \mathrm{l}$ reaction was prepared for the qualitative detection of SARS-CoV-2 by quantitative RT-PCR utilizing $5 \mu$ of extracted RNA, $10 \mu \mathrm{l}$ of $2 x$ PCR buffer, $1 \mu \mathrm{l}$ of the onestep enzyme, and $4 \mu \mathrm{l}$ primer and probe mixture in two separate tubes for $E$ genes and RdRP gene. Thermal cycler was set at $55^{\circ} \mathrm{C}$ for $30 \mathrm{~min}$ ( 1 cycle) for reverse transcription method followed by $95^{\circ} \mathrm{C}$ for $15 \mathrm{~min}$ ( 1 cycle) and then 45 cycles of $95^{\circ} \mathrm{C}$ for $15 \mathrm{~s}$, and $60^{\circ} \mathrm{C}$ for $60 \mathrm{~s}$ (45 cycles) using Bio-Rad CFX-96 RTPCR machine. Real-time PCR was performed for detection of $E$ gene for screening and RdRp gene or ORF1ab gene for confirmation as per the protocol by the manufacturer of the kits available in our laboratory at that time (namely A star Fortitude, Seegene, Labgun, $\mathrm{SD}$ biosensor). The $\mathrm{Ct}$ value for each well was calculated using the cycler's software for confirmatory genes. The data generated in this prospective study was subjected for analysis with the help of appropriate statistical tools and for interpretation of significant outcomes using SPSS 18.0 software.

\section{RESULTS}

A total of 35,391 diagnostic tests for SARSCoV-2 were performed in our laboratory during the study period from April to June 2020. Of these, $589(1.66 \%)$ were reported positive. Amongst those who tested positive, a total of 178 were symptomatic at the time of sample collection, while 411 were asymptomatic. 
Amongst the positives, 401 (68\%) were males, and $189(32 \%)$ were female, and the median age was 46 years.

Further analysis of COVID-19 positive symptomatic patients in this study finds that the common symptoms at the onset of illness were fever $[125 / 178$ (67 \%)], dry cough $[69 / 178(38.7 \%)]$, and myalgia $[45 / 178(25$ $\%)]$; less common were vomiting $12(6.7 \%)$, headache $2(1.1 \%)$ and hemoptysis $2(1.1 \%)$. Among 178 symptomatic patients, the majority, $156(88 \%)$, had one or more high-risk factors for COVID-19 like (a) age $>65$ years (45\%), (b) chronic underlying diseases (e. g., chronic renal failure, diabetes mellitus, chronic liver disease, chronic lung disease, chronic cardiovascular disease; 53\%) (c) hematological malignancy $(23 \%)$ and (d) receiving chemotherapy or immunosuppressive agents (24\%). Among 411 asymptomatic COVID-19 patients, 256 patients $(62.3 \%)$ gave a history of contact with laboratory-confirmed positive cases. This was found to be of statistical significance as only $42 \%$ of symptomatic patients had contact with positive cases.

\section{Comparison of Ct Values (RdRp/ORF1ab) in Asymptomatic and Symptomatic Cases}

In general, as RdRp/ORF1ab Ct values rose, chances of a COVID-19 patient being asymptomatic also rose. Ct values at first diagnosis was positively correlated with patient clinical condition $(r=0.22, p<0.003)$. To better illustrate the magnitude of the effect, Ct was divided into quartiles (Q1, Q2, Q3, and Q4). The Q1 group consisted of cycle numbers < $15, \mathrm{Q} 2$ was cycle numbers between 15.0 to 25.0, Q3 from 25.1 to 30.5 , and Q4 $>30.6$. It was noted that the presence of symptoms was significantly different between the four groups, symptoms predominantly observed in Q1 and Q2. In Table 2, we can observe that $21.8 \%$ of symptomatic patients had Ct values <18. However, when compared to asymptomatic COVID-19 positive patients, the percentage was below $0.5 \%$, which was statistically significant. Considering the predictive power of CT value in correlation with clinical symptoms, we found that $91 \%$ of symptomatic positive patients had $\mathrm{CT}$ value $<25$, whereas the majority of asymptomatic individuals who tested RT-PCR positive had CT value $>25$.
In this study, we have data of 38 patients in which sequential sampling was done at an interval of 6-7 days for up to 21 days. In Table 3 , these 38 patients were divided into two categories, category one: 22 who had symptoms on the first day of testing; category two: 16 patients who were asymptomatic on day 1 of positive testing. From all these 38 patients, four sequential samples each were collected from day 1 to day 21 till they tested RT-PCR negative. Table 3 demonstrates the changes in $\mathrm{Ct}$ values of symptomatic and asymptomatic patients during the 21 day follow-up period. It was observed that symptomatic patients $(n=22)$ with hospitalization and same-day collection of the sample had lower $\mathrm{Ct}$ values in comparison to asymptomatic patients $(n=16)$. The initial low cycle threshold value was directly proportional to the appearance of symptoms, and the high cycle threshold correlated with the absence of symptoms. On repeat sampling after 6-7days, among 22 initial symptomatic patients, only 12 had symptoms (Ct value 25.34 \pm 2.12 ), and in 4 patients, symptoms disappeared, but RT-CR (Ct value $27.86 \pm 1.68$ ) remained positive. Here again, with the disappearance of symptoms, $\mathrm{Ct}$ value was observed rising. In comparison, from asymptomatic cases, when repeat samples were collected after week interval when symptoms started appearing, in 4 cases, there was a decline in $\mathrm{Ct}$ value. On day 21, when the 4th sample was collected, all initially 38 RT-PCR positive symptomatic and asymptomatic individuals showed negative results. Lower $\mathrm{Ct}$ values were observed in specimens from patients who became symptomatic than in those who did not (24 vs. 29; $p=0.008$ ).

\section{DISCUSSION}

The COVID-19 can present as symptomatic or symptomatic infections. The linear dynamic range of the RT-PCR assay and potential presence of inhibitory factors within clinical samples Ct value and log viral load may not be directly proportional. Yet, many authors believe that a higher $\mathrm{Ct}$ value indirectly corresponds to a low viral load [5,6]. The median age of symptomatic subjects was higher $(56.3 \pm 14)$ than that of the asymptomatic subject $(35 \pm 10)$; the difference, however, was not statistically significant. This finding was concordant with studies done by Walsh et al. (Ireland) and Tianmin Xu et al. (China) $[5,6]$. In viral illnesses such as Influenza and SARS, 
viral load has been associated with disease severity [10]. However, a consensus has not yet been achieved regarding COVID-19. To the best of our knowledge, six studies have reported no correlation between $\mathrm{Ct}$ value and clinical severity [11-15]. However, in four studies, samples were more than 100 cases, the majority being hospitalized patients with relatively short follow-up periods. Like our present study, many studies found a positive association between nasopharyngeal SARSCoV-2 Ct values and COVID-19 severity [1618].

Table 1. Demography and clinical characteristics of SARS-CoV-2 positive patients.

\begin{tabular}{|c|c|c|c|}
\hline Characteristics & $\begin{array}{c}\text { Symptomatic, } \mathrm{n} \\
(\%)\end{array}$ & $\begin{array}{c}\text { Asymptomatic, } \\
\mathrm{n}(\%)\end{array}$ & $P$ Value \\
\hline Age, median (IQR) (years) & $56(45-70)$ & $34(20-45)$ & \\
\hline Male sex & $146(82)$ & $255(62)$ & $P<0.001$ \\
\hline Fever $\left(>37.5^{\circ} \mathrm{C}\right)$ & $125(67)$ & - & \\
\hline Cough & $69(38.7)$ & - & \\
\hline Nasal congestion & $65(36.5)$ & - & \\
\hline Myalgia & $45(25.3)$ & - & \\
\hline Rhinorrhoea & $43(24.2)$ & - & \\
\hline Sore throat & $39(21.9)$ & - & \\
\hline Dyspnoea & $27(15.2)$ & - & \\
\hline Vomiting & $12(6.74)$ & - & \\
\hline Haemoptysis & $2(1.12)$ & - & \\
\hline Presence of co-morbidities & $132(74)$ & $58(14.1)$ & $\mathrm{P}<0.001$ \\
\hline Domestic travel history & $45(25.3)$ & $238(58)$ & $P<0.001$ \\
\hline History of Contact with known positive case & $76(42.7)$ & $256(62.3)$ & $P<0.001$ \\
\hline Time from initial symptoms to diagnosis, median (IQR) (days) & $14(8-17)$ & & \\
\hline
\end{tabular}

Table 2. Comparison of $\mathrm{Ct}$ values in symptomatic $(n=178)$ and asymptomatic individuals $(n=411)$

\begin{tabular}{lccc}
\hline Average Ct Value (RdRp/ORF1ab) & Symptomatic $n(\%)$ & Asymptomatic $n(\%)$ & P value \\
\hline$\leq 15$ & $05(2.8)$ & 00 & $<0.02$ \\
17 & $34(19)$ & $02(0.5)$ & $<0.001$ \\
20 & $56(31.5)$ & $23(5.6)$ & $<0.001$ \\
23 & $67(37.6)$ & $42(10.2)$ & $<0.01$ \\
26 & $16(9.1)$ & $147(35.8)$ & $<0.001$ \\
28 & 00 & $101(24.6)$ & $<0.0008$ \\
\hline
\end{tabular}


Table 3. Variation observed in Ct values upon sequential sampling and symptomatology $(n=38)$.

$$
\text { Symptomatic at the admission }(n=22) \quad \text { Asymptomatic at the admission }(n=16)
$$

\begin{tabular}{|c|c|c|c|c|c|c|c|c|c|}
\hline \multirow{3}{*}{$\begin{array}{l}\text { Sample } \\
\text { No. } \\
\text { (Test } \\
\text { Days) }\end{array}$} & \multirow{3}{*}{$\begin{array}{c}\text { RT-PCR } \\
\text { Ct Value } \\
\text { (Mean } \pm \\
\text { SD) }\end{array}$} & \multicolumn{3}{|c|}{ Follow up $(n=22)$} & \multirow{3}{*}{$\begin{array}{c}\text { RT-PCR } \\
\text { Ct Value } \\
\text { (Mean + } \\
\text { SD) }\end{array}$} & \multicolumn{3}{|c|}{ Follow up (16) } & \multirow{3}{*}{$\begin{array}{c}P \\
\text { value }\end{array}$} \\
\hline & & \multirow{2}{*}{$\begin{array}{c}\text { Symptoms } \\
\text { persist } \\
\text { (PCR } \\
\text { Positive) }\end{array}$} & \multicolumn{2}{|c|}{$\begin{array}{l}\text { Symptoms } \\
\text { disappear }\end{array}$} & & \multirow{2}{*}{$\begin{array}{l}\text { Symptoms } \\
\text { persist } \\
\text { (PCR } \\
\text { Positive) }\end{array}$} & \multicolumn{2}{|c|}{$\begin{array}{l}\text { Symptoms } \\
\text { disappear }\end{array}$} & \\
\hline & & & $\begin{array}{c}\text { PCR } \\
\text { Positive }\end{array}$ & $\begin{array}{c}\text { PCR } \\
\text { Negative }\end{array}$ & & & $\begin{array}{c}\text { PCR } \\
\text { Positive }\end{array}$ & $\begin{array}{c}\text { PCR } \\
\text { Negative }\end{array}$ & \\
\hline $\begin{array}{l}\text { Sample } \\
1 \text { (Day } \\
1 \text { ) }\end{array}$ & $23 \pm 3.8$ & 22 & 0 & 0 & $28 \pm 4.6$ & 0 & 16 & 0 & 0.04 \\
\hline $\begin{array}{l}\text { Sample } \\
2 \text { (Day } \\
6-7)\end{array}$ & $\begin{array}{l}26 \pm 2.2 \\
(n=16)\end{array}$ & 12 & 4 & 6 & $27 \pm 2.8$ & 4 & 10 & 2 & 0.01 \\
\hline $\begin{array}{l}\text { Sample } \\
3 \text { (Day } \\
10-14)\end{array}$ & $\begin{array}{c}29 \pm 2.5 \\
(n=5)\end{array}$ & 4 & 1 & 17 & $32 \pm 1.4$ & 0 & 8 & 8 & 0.02 \\
\hline $\begin{array}{l}\text { Sample } \\
4 \text { (Day } \\
21 \text { ) }\end{array}$ & $\begin{array}{c}\text { All } \\
\text { negative }\end{array}$ & 0 & 0 & 22 & $\begin{array}{c}\text { All were } \\
\text { negative } \\
\text { on RT- } \\
\text { PCR } \\
\text { testing }\end{array}$ & 0 & 0 & 16 & \\
\hline
\end{tabular}

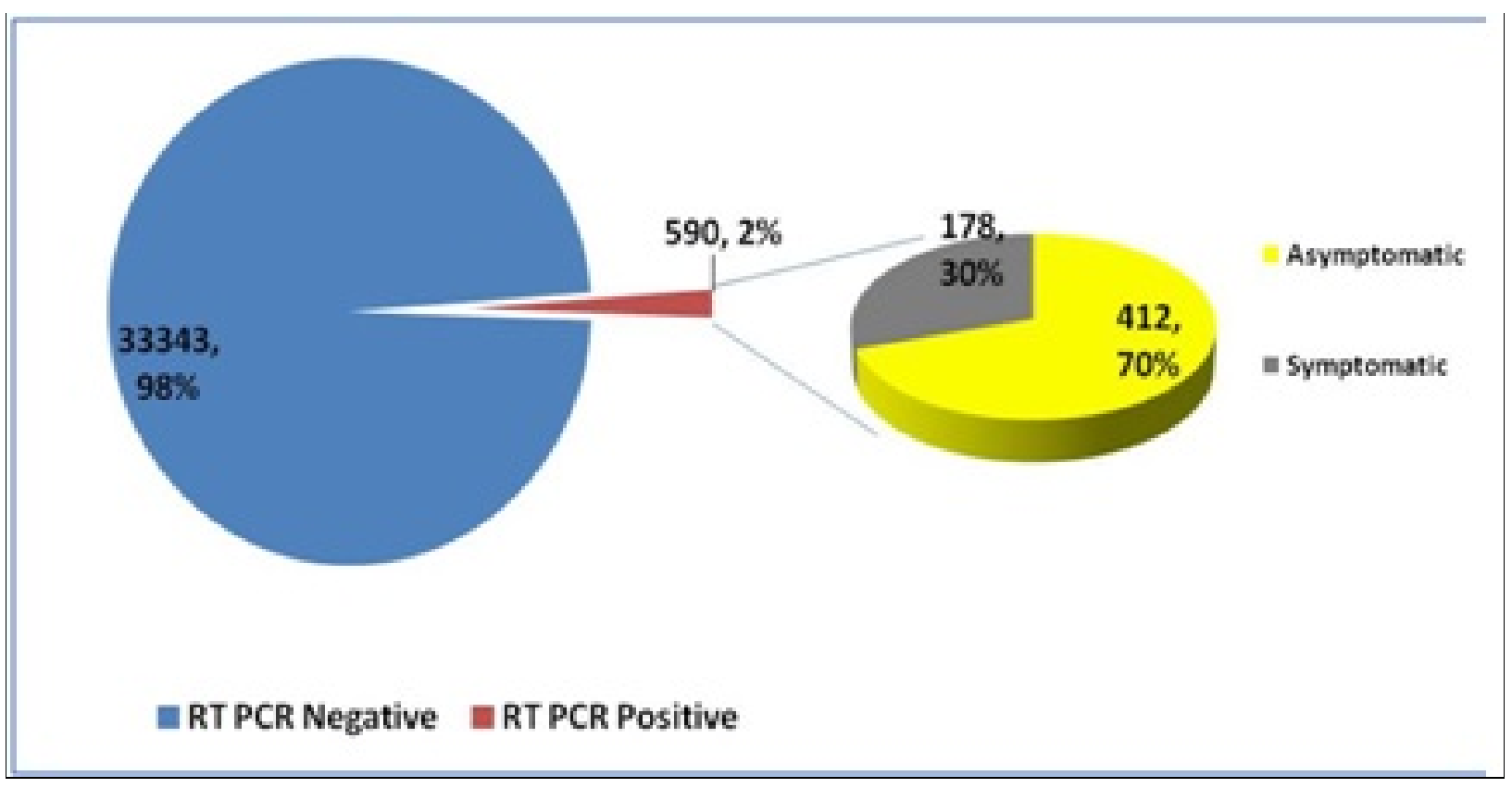

Image 1. COVID-19 RT-PCR Result for study subjects. 


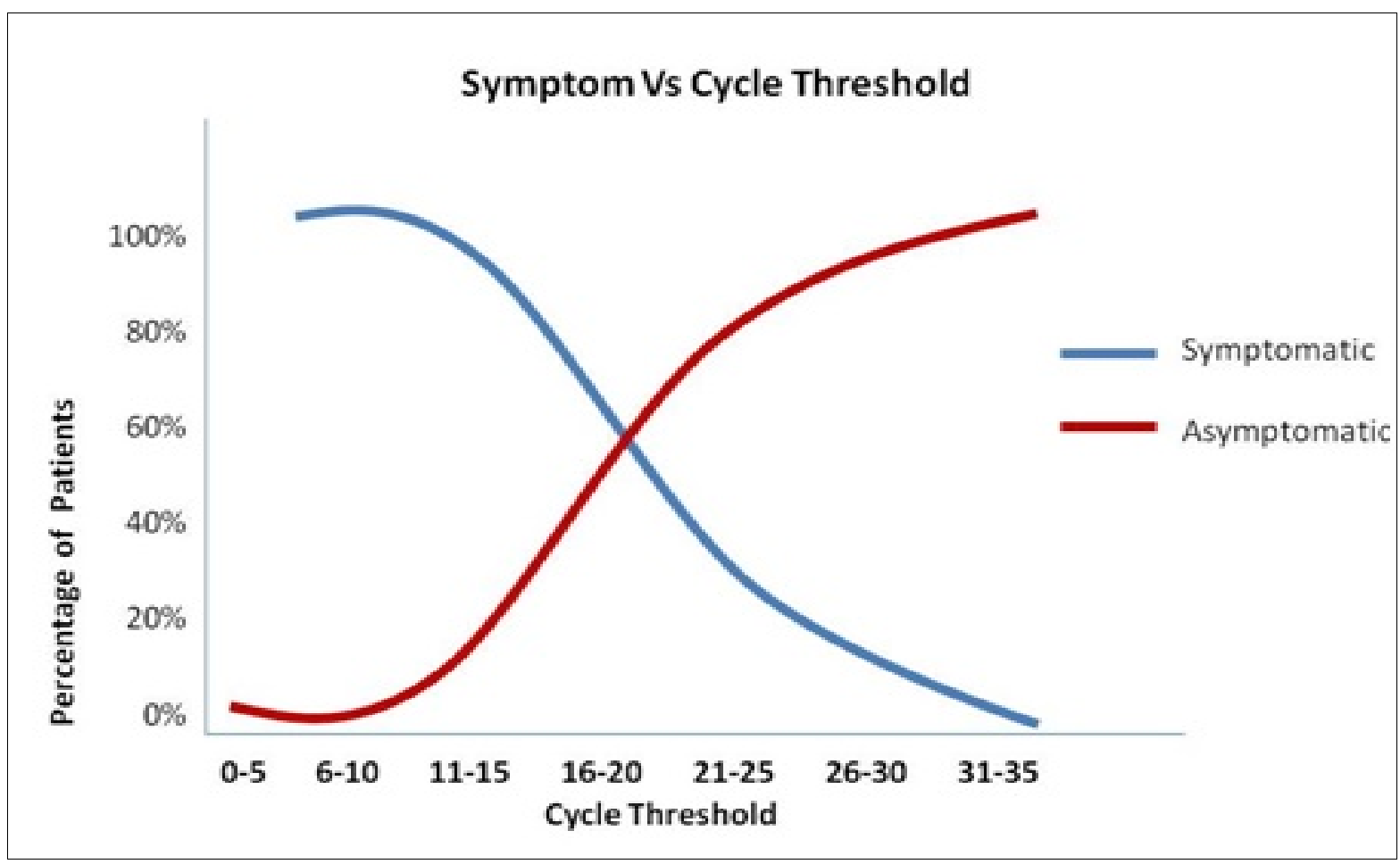

Image 2. Correlation between presence of symptoms and Cycle threshold (Ct value).

Compared to findings reported by these studies, our study has a follow-up of four weeks and included non-hospitalized patients' sequential samples. The above studies also found an association between low Ct value, higher viral loads, and grave symptoms. Many authors agree that the $\mathrm{Ct}$ value can indicate viral load [19-21]. The presence of signs and symptoms at diagnosis were associated with low $\mathrm{Ct}$ values. Our findings are in line with those recently published by others [21]. In a study with nasopharyngeal samples in 76 patients, the mean viral load of severe cases was found around 60 times higher than that of mild cases. This relationship was maintained from the early to later stages of the infection [11]. In the present study, $16 \%$ of asymptomatic individuals had a $\mathrm{Ct}$ value of $<25$, indicating a high viral load in the nasopharynx. In our research, many cases in the asymptomatic phase got diagnosed because of a positive RT PCR. The exact reason some individuals do not manifest clinical symptomatology of COVID-19, despite a high viral load in the throat, remains unclear [22]. Such asymptomatic cases of COVID-19 are an essential source of viral shedding and thus possible transmission, and this needs to be controlled by surveillance of asymptomatic individuals. While there is evidence in SARSCoV-2 infection for viral shedding both in asymptomatic patients and in patients after symptom resolution, the correlation between detectable viral RNA (and thus Ct value) and transmissibility is still unclear [23]. A positive RT-PCR report does not necessarily represent evidence of viral transmission as this testing method cannot differentiate between infective and inactive viruses. Wolfel et al. demonstrated that live virus could be cultured from nasal/throat and sputum samples in symptomatic patients with positive SARS-CoV2 PCR; however, no live virus was isolated from symptom-free patients with high cycle threshold [24]. A cohort study showed that among 303 patients with SARS-CoV-2 infection in Cheonan, Korea, the Ct values in asymptomatic patients were similar to those in symptomatic patients [25]. The reason for this inconsistency between these findings and our's could be a difference in sample size, geographic location, immunity, and genetic variability of the study population. In our study population, patients have been included from different regions of State and not from a single facility, treatment center, or hospital. Given the strong association between $\mathrm{Ct}$ values and symptoms presence, $\mathrm{Ct}$ value on initial SARSCoV-2 testing may significantly predict outcomes, especially for patients admitted to the hospital. Although $\mathrm{Ct}$ value is a surrogate predictor of clinical outcomes, our data does not find a clinically meaningful cut-off that 
could be used for triaging of patients admitted to the hospital.

Rui Zhou et al. also reported median Ct value of asymptomatic patients (39.0, interquartile range (IQR) 37.5-39.5) was significantly higher than that of symptomatic (24.5, IQR 22.2-27.0), indicating a lower viral load in asymptomatic. However, in their study, the viral shedding duration remained almost similar in the two groups (7 days, IQR 5-14 days vs. eighth days, IQR 5-16 days)[23]. These results bring another important finding into foray that the initial cycle threshold value does not give any information regarding virus clearance or, in other words, the end of possible virus transmission. Thus, duration of symptoms and $\mathrm{Ct}$ value on the initial SARSCoV-2 test are independent predictors of clinical outcomes and potentially useful patient trajectory indicators.

This study has also some limitations. The study is a laboratory-based semiquantitative method done during the lockdown phase, and sequential sampling data is only available for 38 patients. It was not possible to record the long-term follow-up and recovery of all patients. Some of these samples came to our laboratory from far-off areas of the province, $\mathrm{Ct}$ value may vary depending on the sample collection method and its storage and transport conditions. Besides, different RT-PCR kits for the same viral load may give different $\mathrm{Ct}$ values.

In conclusion, there are different thoughts regarding the correlation between cycle threshold and the presence or absence of symptoms. In our study, we do find a clear correlation between lower $\mathrm{Ct}$ values and the presence of clinical signs. Also, as reported previously, older age and co-morbidities were significantly more associated with symptomatic COVID-19 patients. Upon sequential testing, the virus clearing from the throat (as indicated by negative RT-PCR) was similar regardless of initial symptomatology/Ct value.

\section{ACKNOWLEDGMENTS}

Declaration of Conflicting Interests: The authors declare that they have no conflict of interest.

Authors Contributions: Jyotsna Agarwal designed and supervised the study. Jaya Garg edited the manuscript; Vikramjeet Singh performed laboratory work and prepared the first draft of the manuscript. Mohammad Saquib collected the sample and clinical data. Anupam Das performed the molecular work, and Manodeep Sen performed data analysis.

Funding: Not applicable

\section{REFERENCES}

1. Cucinotta D, Vanelli M. WHO Declares COVID-19 a Pandemic. Acta Biomed. 2020 Mar 19;91(1):157-160. doi: 10.23750/abm.v91i1.9397. PMID: 32191675; PMCID: PMC7569573.

2. National Centre for Infectious Diseases, Chapter of Infectious Disease Physicians, Academy of Medicine, Singapore. Position Statement from the National Centre for Infectious Diseases and the Chapter of Infectious Disease Physicians, Academy of Medicine, Singapore. 2020. May Available from: https://www.ams.edu.sg/view-

pdf.aspx?file=media\%5c5556_fi_331.pdf\&ofile=Peri od+of+Infectivity+Position+Statement+(final)+23-520+(logos).pdf. Accessed June 12, 2020.

3. Mizumoto K, Kagaya K, Zarebski A, et al. Estimating the asymptomatic proportion of coronavirus disease 2019 (COVID-19) cases on board the Diamond Princess cruise ship, Yokohama, Japan, 2020. Euro Surveill 2020; 25 (10):2000180. doi: 10.2807/15607917.ES.2020.25.10.2000180.

4. Bai Y, Yao L, Wei $T$, et al. Presumed asymptomatic carrier transmission of COVID-19. JAMA 2020; 323 (14):1406-1407.

5. Xu T, Chen C, Zhu Z, et al. Clinical features and dynamics of viral load in imported and nonimported patients with COVID-19. Int J Infect Dis 2020; 94 (5):68-71. doi: 10.1016/j.jijid.2020.03.022

6. Walsh KA, Jordan K, Clyne B, et al., SARSCoV-2 detection, viral load and infectivity over the course of an infection, Journal of Infection, 2020; 81 (3):357-371.

7. Han A, Czajkowski LM, Donaldson A, et al. A Dose-Finding Study of a Wild-Type Influenza $\mathrm{A}(\mathrm{H} 3 \mathrm{~N} 2)$ Virus in a Healthy Volunteer Human Challenge Model. Clin. Infect. Dis. 2019; 69 (12):2082-2090.

8. Chu CM, Poon LLM, Cheng VCC, et al. Initial Viral Load and the Outcomes of SARS. CMAJ 2004; 171 (11):1349-1352.

9. Arons MM, Hatfield $\mathrm{KM}$, Reddy $\mathrm{SC}$, et al. Presymptomatic SARS-CoV-2 Infections and Transmission in a Skilled Nursing Facility. N Engl J Med 2020; 382(22):2081-2090. doi: 10.1056/NEJMoa2008457

10. He X, Lau EHY, Wu $P$, et al. Temporal Dynamics in Viral Shedding and Transmissibility of COVID-19. Nat Med 2020; 26 (9): 672-675. 
11. To KK-W, Tsang OT-Y, Leung W-S, et al. Temporal Profiles of Viral Load in Posterior Oropharyngeal Saliva Samples and Serum Antibody Responses during Infection by SARSCoV-2: An Observational Cohort Study. Lancet Infect. Dis. 2020;20(5):565-574.

12. Zou L, Ruan F, Huang M, et al. SARS-CoV-2 Viral Load in Upper Respiratory Specimens of Infected Patients. N Engl J Med 2020; 382 (12): 1177-1179.

13. Jacot D, Greub G, Jaton K, et al. Viral Load of SARS-CoV-2 across Patients and Compared to Other Respiratory Viruses. Microbes Infect 2020; 22(10):617-621.

14. Karahasan AY, Sarinoglu RC, Bilgin $H$, et al. Relationship of the Cycle Threshold Values of SARS-CoV-2 Polymerase Chain Reaction and Total Severity Score of Computerized Tomography in Patients with COVID-19. Int. J Infect Dis 2020; 101: 160-166.

15. Westblade LF, Brar G, Pinheiro LC, et al. SARS-CoV-2 Viral Load Predicts Mortality in Patients with and without Cancer Who Are Hospitalized with COVID-19. Cancer Cell 2020; 38 (5):661-671.

16. Pujadas E, Chaudhry $F$, McBride $R$, et al. SARS-CoV-2 Viral Load Predicts COVID-19 Mortality. Lancet Respir Med 2020, 8(9), e70, doi: 10.1016/S2213-2600(20)30354-4.

17. Faíco-Filho KS, Passarelli VC, Bellei N. Is Higher Viral Load in SARS-CoV-2 Associated with Death? Am J Trop Med Hyg 2020;103(5):20192021.

18. Shlomai A, Ben-Zvi H, Glusman Bendersky A, et al. Nasopharyngeal Viral Load Predicts Hypoxemia and Disease Outcome in Admitted COVID-19 Patients. Crit Care 2020, 24 (1), 539.

19. Lescure FX, Bouadma L, Nguyen D, et al. Clinical and virological data of the first cases of COVID-19 in Europe: a case series. Lancet Infect Dis 2020; 20(6):697-706.

20. Liu Y, Yan LM, Wan L, et al. Viral dynamics in mild and severe cases of COVID-19. Lancet Infect Dis 2020; 20 (6):656-657.

21. Pan $Y$, Zhang $D$, Yang $P$, et al. Viral load of SARS-CoV-2 in clinical samples. Lancet Infect Dis 2020; 20 (4):411-412.

22. $\mathrm{Yu} F$, Yan $\mathrm{L}$, Wang $\mathrm{N}$, Yang $\mathrm{S}$, et al. Quantitative detection and viral load analysis of SARS-CoV-2 in infected patients. Clin Infect Dis 2020; 71 (15):793-798 doi: 10.1093/cid/ciaa345.

23. Zhou R, Li F, Chen F, et al. Viral dynamics in asymptomatic patients with COVID-19. Int J Infect Dis 2020; 96: 288-290.
24. Wolfel R, Corman VM, Guggemos W, et al. Virological assessment of hospitalized patients with COVID-2019. Nature 2020; 581 (7809):465-469. doi:10.1038/s41586-020-2196-x.

25. Lee S, Kim T, Lee E, et al. Clinical course and molecular viral shedding among asymptomatic and symptomatic patients with SARS-CoV-2 infection in a community treatment center in the Republic of Korea. JAMA Intern Med 2020; 180 (11): 14471452. doi: 10.1001/jamainternmed.2020.3862. 